\title{
Research on the Communication Quality of the Residents' Health in One of China's Northwest Cities
}

\author{
Jinliang Ye \\ Department of Health Management \\ Xi'an Medical University \\ Xi'an, China
}

\begin{abstract}
With the development of society and economy in our country, the chronic noninfectious diseases caused by unhealthy lifestyles have accounted for more than $75 \%$ of all the diseases. Therefore, more and more people began to look at their lives from a healthy perspective. However, due to residents' different channels to health information, understanding deviation towards health is caused. How to use the media to obtain health information and improve living quality has become an important research issue. This paper conducts researches on the popularization of the residents healthy quality in one of Chinese northwest cities from three levels of the interpersonal relationship, community, and mass communication to improve the effectiveness and pertinence of health communication activities.
\end{abstract}

Keywords-community residents; health behavior; communication quality

\section{INTRODUCTION}

With the quickening pace of life and the decreasing exercise time, more and more chronic diseases show a younger trend, causing great distress to people's life. Therefore, advocating a healthy lifestyle has become the main way to solve this kind of problems. It is necessary to understand the current situation of people's health spreading quality in order to improve the effectiveness of all kinds of health communication activities. Hence, this study conducts researches on the spreading quality of the residents' health in a city in the northwest based on the current situation.

\section{RESEARCH OBJECTS AND METHODS}

This study uses the questionnaire of citizen health communication quality to carry out the investigation among residents in western cities and inquiries the status of people's health communication quality by means of interviewing passerby and residents in their homes. The sample groups of people are representative for having varied occupations and covering people of all ages and different educational backgrounds. Two hundred questionnaires are sent to respondents mainly in the ways of responding alone and secretly to reduce the misguidance of investigators to respondents, and the final data is analyzed by SPSS software.

\section{A. Characteristics of Research Objects}

The proportion of men and women in the sample groups is $1: 1.3$. In the distribution, the age of and under 20 years accounted for 6.5\%; people of 21-30 years accounted for $29 \%$, people of 31-40 years old accounted for, people of 41 50 accounted for $17 \%$, people of 51-60 accounted for $14 \%$, and people more than 60 years old accounting for $6.5 \%$.

\section{B. Survey of Residents' Knowledge on Health}

In the residents, only $1.5 \%$ were not interested in the information about health, but more than half were interested in it "Table I". This shows that people have a great demand for health information dissemination activities. Generally speaking, driven by strong interests, people are familiar with the health knowledge; however, "Table II" shows that only $36 \%$ of people reach this level, and more than half $(54 \%)$ of people have a simple understanding of health knowledge, and people's health knowledge is not equal to their interests on health. From the two sets of data above, we can make a conclusion that residents hope to get more information about health, but the health communication activities - an important way to obtain the information on health, cannot fully meet this demand, and there is still much work to do in health communication.

TABLE I. THE EXTENT OF RESIDENTS’ INTERESTS ON HEALTH INFORMATION

\begin{tabular}{|l|l|l|l|l|}
\hline & frequency & percentage & $\begin{array}{c}\text { valid } \\
\text { percentage }\end{array}$ & $\begin{array}{l}\text { cumulative } \\
\text { percentage }\end{array}$ \\
\hline $\begin{array}{l}\text { Very } \\
\text { interested }\end{array}$ & 55 & 27.5 & 27.5 & 27.5 \\
\hline Interested & 109 & 54.5 & 54.5 & 54.5 \\
\hline $\begin{array}{l}\text { Slightly } \\
\text { interested }\end{array}$ & 33 & 16.5 & 16.5 & 16.5 \\
\hline $\begin{array}{l}\text { Not } \\
\text { interested }\end{array}$ & 3 & 1.5 & 1.5 & 1.5 \\
\hline Total & 200 & 100 & 100 & 100 \\
\hline
\end{tabular}


TABLE II.

THE EXTENT OF RESIDENTS’ MASTERY OF HEALTH INFORMATION

\begin{tabular}{|l|l|l|l|l|}
\hline & frequency & percentage & $\begin{array}{c}\text { valid } \\
\text { percentage }\end{array}$ & $\begin{array}{c}\text { cumulative } \\
\text { percentage }\end{array}$ \\
\hline Skillful & 7 & 3.5 & 3.5 & 3.5 \\
\hline Familiar & 72 & 36.0 & 36.0 & 36 \\
\hline Know & 108 & 54.0 & 54.0 & 54 \\
\hline Ignorant & 13 & 6.5 & 6.5 & 6.5 \\
\hline Total & 200 & 100 & 100 & 100 \\
\hline
\end{tabular}

\section{MASS COMMUNICATION IS RESIDENTS'MAIN SOURCE OF HEALTH INFORMATION}

The main channels for residents to obtain health information: $60 \%$ of the people chose the mass communication "Table III", interpersonal communication was in the second place, and group communication accounted for only $7.5 \%$. This set of data reflects that the public health communication and interpersonal health communication are the most important ways of health communication. Media information dissemination activities such as television, radio, newspapers, magazines, Internet and others have penetrated into all aspects of social life, and the mass health communication activities do not play its full role.

TABLE III. THE MAIN CHANNELS FOR RESIDENTS TO OBTAIN HEALTH INFORMATION

\begin{tabular}{|l|l|l|l|l|}
\hline & frequency & percentage & $\begin{array}{c}\text { valid } \\
\text { percentage }\end{array}$ & $\begin{array}{l}\text { cumulative } \\
\text { percentage }\end{array}$ \\
\hline $\begin{array}{l}\text { Interpersonal } \\
\text { communication }\end{array}$ & 65 & 32.5 & 32.5 & 32.5 \\
\hline $\begin{array}{l}\text { Group } \\
\text { communication }\end{array}$ & 15 & 7.5 & 7.5 & 7.5 \\
\hline $\begin{array}{l}\text { Mass } \\
\text { communication }\end{array}$ & 120 & 60.0 & 60.0 & 60 \\
\hline Total & 200 & 100.0 & 100.0 & 100 \\
\hline
\end{tabular}

\section{RESEARCH RESULTS}

\section{A. The Measurement of Interpersonal Health Communication}

On the issue of the main factors contributing to residents' acceptance of health information, "Fig. 1" shows that people holding the opinion that communicators should be equipped with medical knowledge account for about $61 \%$. This phenomenon shows that although the frequent news of nervous physician-patient relationship in recent years, doctors with medical knowledge are the most convincing factors for patients to accept health information.

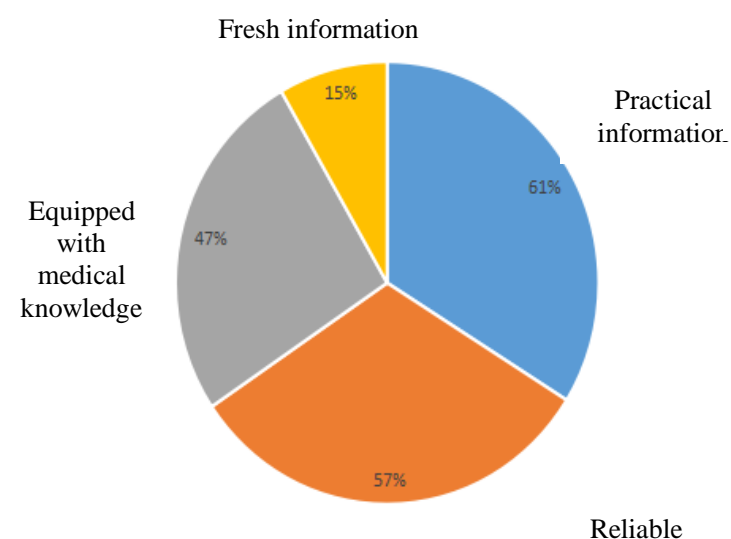

information

Fig. 1. Main factors of residents accepting health information.

When treating others' dissemination of health information, the surveys "Table IV" and "Table V" show that $92 \%$ residents are able to think firstly and then accept. It can be seen that when accepting other people's health information, currently the majority can do active thinking instead of receiving passively. At the same time, $74 \%$ residents can think actively on their own, and identify the authenticity of information passed by others. The results further prove that the high level of interpersonal health communication quality of current residents as recipients.

TABLE IV. THE ATtitudes OF TREATING HEALTH INFORMATION PASSED BY OTHERS

\begin{tabular}{|l|l|l|l|l|}
\hline & frequency & percentage & $\begin{array}{c}\text { valid } \\
\text { percentage }\end{array}$ & $\begin{array}{l}\text { cumulative } \\
\text { percentage }\end{array}$ \\
\hline $\begin{array}{l}\text { Accept } \\
\text { totally }\end{array}$ & 11 & 5.5 & 5.5 & 5.5 \\
\hline $\begin{array}{l}\text { Accept } \\
\text { Dialectically }\end{array}$ & 184 & 92 & 92 & 92 \\
\hline Not accept & 5 & 2.5 & 2.5 & 2.5 \\
\hline Total & 200 & 100 & 100 & 100 \\
\hline
\end{tabular}

TABLE V. WHETHER RESIDENTS CAN FINDTHE PROBLEMS IN THE INFORMATION PASSED BY OTHERS

\begin{tabular}{|l|l|l|l|l|}
\hline & frequency & percentage & $\begin{array}{c}\text { valid } \\
\text { percentage }\end{array}$ & $\begin{array}{l}\text { cumulative } \\
\text { percentage }\end{array}$ \\
\hline Can & 148 & 74.0 & 74.0 & 74.0 \\
\hline Cannot & 52 & 26.0 & 26.0 & 26 \\
\hline Total & 200 & 100.0 & 100.0 & 100 \\
\hline
\end{tabular}

\section{B. Measurement of Group Health Communication Quality}

In the measurement of group health communication quality, "Table VI" shows that $39.5 \%$ of people never participate in such activities, $56 \%$ people attend occasionally, and only $4.5 \%$ of the people are keen on health communication activities. This set of data shows that group health communication activities currently are not fully carried out: the reasons are that on the one hand, the enthusiasm of people's participation is not high; on the other hand, the whole society are not fully aware of the enormous potential in health of group communication. More than half of the respondents participate in similar health lectures, community health education and health promotion activities 
occasionally, which is in stark contrast to the situation of interests on health knowledge that "Table II" reflects.

TABLE VI. The ENGAgEMENT OF GROUP HeAlth ACTIVITIES

\begin{tabular}{|l|l|l|l|l|}
\hline & frequency & percentage & $\begin{array}{c}\text { valid } \\
\text { percentage }\end{array}$ & $\begin{array}{l}\text { cumulative } \\
\text { percentage }\end{array}$ \\
\hline $\begin{array}{l}\text { Regularly } \\
\text { participate }\end{array}$ & 9 & 4.5 & 4.5 & 4.5 \\
\hline $\begin{array}{l}\text { Occasionally } \\
\text { participate }\end{array}$ & 112 & 56.0 & 56.0 & 60.5 \\
\hline $\begin{array}{l}\text { Never } \\
\text { participate }\end{array}$ & 79 & 39.5 & 39.5 & 39.5 \\
\hline Total & 200 & 100.0 & 100.0 & 100 \\
\hline
\end{tabular}

It can be seen from "Table VII" and "Table VIII", in the residents of participating in health communication activities, $57 \%$ are skeptical to the activities, $45 \%$ have the experience of being misled by groups health communication activities. The phenomenon is very common in some medical products promotion activities. Objectively speaking, the valuable group health communication activities at present such as the public outreach activities carried by regular of medical institutions are not enough.

TABLE VII. WHETHER THE RESIDENTS ARE MISGUIDED IN GROUP HEALTH COMMUNICATION

\begin{tabular}{|l|l|l|l|l|}
\hline & frequency & percentage & $\begin{array}{c}\text { valid } \\
\text { percentage }\end{array}$ & $\begin{array}{l}\text { cumulative } \\
\text { percentage }\end{array}$ \\
\hline Frequently & 89 & 45 & 45 & 45 \\
\hline Occasionally & 62 & 31 & 31 & 31 \\
\hline Never & 49 & 24 & 24 & 24 \\
\hline Total & 200 & 100.0 & 100 & 100.0 \\
\hline
\end{tabular}

TABLE VIII. The AtTitudes to Group HeAlth COMMUNiCATion ORGANIZERS

\begin{tabular}{|l|l|l|l|l|}
\hline & frequency & percentage & $\begin{array}{c}\text { valid } \\
\text { percentage }\end{array}$ & $\begin{array}{l}\text { cumulative } \\
\text { percentage }\end{array}$ \\
\hline $\begin{array}{l}\text { Totally } \\
\text { believe }\end{array}$ & 25 & 13 & 13 & 13 \\
\hline Suspect & 113 & 57 & 57 & 57 \\
\hline Reject & 62 & 30 & 30 & 30 \\
\hline Total & 200 & 100.0 & 100.0 & 100.0 \\
\hline
\end{tabular}

\section{Measurement of the Mass Health Communication Quality}

According to the survey, the primary channel for citizens to obtain health information is mass media.The top three media are: newspapers, television, and internet "Fig. 2".

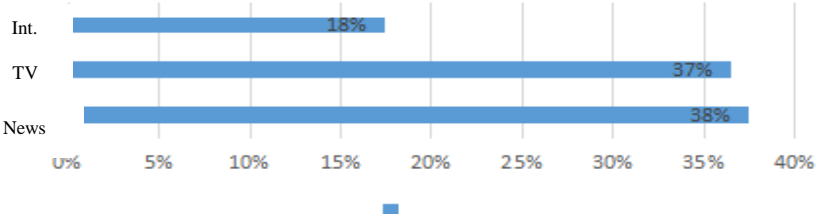

Fig. 2. The mass media channels of citizens to obtain health information.

Newspaper has advantages of wide coverage, strong selectivity and that it can be read repeatedly and so on; it is an important means to carry out health education. Television can be transformed into simple and visualized pictures and interpretation to arouse audiences ' interests and demand for health knowledge. As an open media, the Internet combining with various communication channels is more targeted and interactive in communication.

Although the mass media is closely to the public, it is a remarkable fact that the public health communication activities still have crisis of confidence in the public. In addition to that the choice of audience towards the media can reflect the status of current mass media in health communication, the attitude of the audience is also an important index. As shown in "Table IX", the majority respondents $(89 \%)$ are skeptical to health communication activities of the mass media; people of distrust (6.5\%) and full trust $(4.5 \%)$ are very few. This set of data shows that there exist crisis of confidence of mass media activities in the field of health communication, and the audience do not completely trust it.

TABLE IX. CITIZENS' ATtITUdES TOWARdS VARIOUS HEALTH COMMUNICATION ACTIVITIES IN MASS MEDIA

\begin{tabular}{|l|l|l|l|l|}
\hline & frequency & percentage & $\begin{array}{c}\text { valid } \\
\text { percentage }\end{array}$ & $\begin{array}{l}\text { cumulative } \\
\text { percentage }\end{array}$ \\
\hline $\begin{array}{l}\text { Totally } \\
\text { trust }\end{array}$ & 9 & 4.5 & 4.5 & 4.5 \\
\hline skeptical & 178 & 89.0 & 89.0 & 89 \\
\hline disbelieve & 13 & 6.5 & 6.5 & 6.5 \\
\hline Total & 200 & 100.0 & 100.0 & 100.0 \\
\hline
\end{tabular}

The reasons of "Table X" mainly are the existence of "paradox" in public health communication. Mass media lacks screening mechanism in the health dissemination, and media workers cannot become guards in health knowledge, which result in the low trust in mass media.

TABLE X. WHETHER RESIDENTS HAVE EXPERIENCE OF BEING GIVEN DIFFERENT INTERPRETATION OF THE SAME QUESTION ABOUT HEALTH

\begin{tabular}{|l|l|l|l|l|}
\hline & frequency & percentage & $\begin{array}{c}\text { valid } \\
\text { percentage }\end{array}$ & $\begin{array}{l}\text { cumulative } \\
\text { percentage }\end{array}$ \\
\hline $\begin{array}{l}\text { Regularly } \\
\text { encounter }\end{array}$ & 43 & 21.5 & 21.5 & 21.5 \\
\hline $\begin{array}{l}\text { Come } \\
\text { across }\end{array}$ & 124 & 62.0 & 62.0 & 62 \\
\hline Never meet & 33 & 16.5 & 16.5 & 16.5 \\
\hline Total & 200 & 100.0 & 100.0 & 100.0 \\
\hline
\end{tabular}

V. RESEARCH ON CHANNELS OF HEALTH COMMUNICATION QuALITY BASED ON THE RESIDENTS IN A WESTERN CITY

Based on the summary from the research above, we can know that the most important channels for the local residents to obtain health information are newspaper, TV and internet. Therefore, combined with real information, this research explores how to do a good job of leading the residents to nurture health communication quality.

According to the results of the research, paper media ranked second for the audiences to receive health information. However, the current health information editors in paper media do not have medical knowledge. Therefore, it 
is very necessary that doctors with rich experience review the papers to ensure its scientific nature.

Television has an irreplaceable role in the popularization of health knowledge and health awareness of the whole society. At present, local health programs are very few, and the distribution is messy, and vitality is not strong. Therefore, the television media workers should cherish their credibility, adhere to their professional conscience and ethics, check the health information carefully, review the health television programs strictly, investigate and punish television media, enterprises and individuals seriously who post false advertisement in the name of health communication.

Internet has the advantages of improving the interaction: the interactive forms of health websites, traditional BBS forum, routine questionnaire. Besides, the methods of expert online consultation, interactive video, telemedicine and other means should be used to highlight the mutual motivation, make website information "moving" as much as possible to form two-way communication and information interaction with users.

\section{CONCLUSION}

In short, the residents wish that health programs should combine with the health needs of public in social reality, and the contents of the programs are rich. By subdividing the topics on health, the programs can not only satisfy the audiences' requirements of healthcare and give special attention to potential problem, but also broadcast the fastest health information and spread right health concepts to improve health conditions and serve the public better.

\section{REFERENCES}

[1] Duan Jingsu, Du Junfei et al. Introduction to Media Literacy [M]. Fujian: Fujian People's Publishing House, 2007

[2] Denis - Mcguire, Audience Analysis [M]. Beijing: China Renmin University Press, 2006

[3] Chen Yang. Introduction to Research Methods of Mass Communication [M]. Beijing: China Renmin University Press, 2007

[4] Guo Qingguang, Communication Course [M]. Beijing: China Renmin University Press, 2003

[5] Molly. research of TV audiences and cultural [M]. Beijing: Xinhua Publishing House, 2005

[6] Zhang Mengxin, Li Qin. Health Communication and Social Panic [J]. Contemporary Communication. 2003 (05)

[7] Zhang Zili. "Health Communication" and "Communication in Health": Analysis on the Two Branches of Health Communication [J]. Modern Communication. (2003) (01) 